Marquette University

e-Publications@Marquette

Philosophy Faculty Research and Publications

Philosophy, Department of

4-7-2011

\title{
Conflict and Cosmopolitanism in Plato and the Stoics
}

Owen Goldin

Marquette University, owen.goldin@marquette.edu

Published version. Apeiron, Vol. 44, No. 3, (April 2011), pp.264-286. DOI. (C) 2011 Walter de Gruyter. Used with permission. 


\title{
Conflict and Cosmopolitanism in Plato and the Stoics ${ }^{1}$
}

\author{
Owen Goldin (Milwaukee) \\ Department of Philosophy \\ Marquette University \\ Milwaukee, WI 53201-1881 \\ Owen.Goldin@Marquette.edu
}

According to a number of contemporary philosophers, the moral demands to care for those of the same nationality are not more pressing than the demands to care for those of a different nation, at least in regard to basic needs and rights. They conclude that national boundaries have little or no moral relevance. The Stoics are admired for being the first in the West to have drawn this conclusion. There is some truth to this; although the Hellenistic era lacked our concept of the "nation", they did have the notion of a people, an ethnos, and did deny that the obligations of justice hold only among members of the same people. However, Stoics, like other ancient philosophers, had complex and nuanced views on this matter. This can be seen especially in the political writings of Cicero, which show clear and direct Stoic influence. Cicero's writings present evidence that some Stoics, like contemporary political thinkers attracted to cosmopolitan ideals, struggled with the tension between the demands of moral impartiality and the recognition of special bonds of moral obligation between those of the same ethnos.

If Stoic cosmopolitan thought is to be fully appreciated, it needs to be considered in its philosophical context, as developed in response to earlier philosophical arguments and articulations of everyday morality. A number

1 Early versions of this paper were presented at the University of Ottawa, the Society for Ancient Greek Philosophy (Fordham, Lincoln Center), the Northeastern Political Science Association (Philadelphia), and the Marquette University Midwest Seminar in Ancient and Medieval Philosophy. Thanks are to due to all of these audiences, and also to Arun Iyer, Kim Thao Tran, and especially Darrell Dobbs, for comments, assistance, and advice. 
of Peripatetic and Stoic philosophers were responding to a problematic passage in Plato's Republic, in which Socrates asserts that barbarians (that is, non-Greeks) are by nature alien (allotrioi) to Greeks, and are accordingly natural enemies, to be treated differently in warfare from fellow Greeks, who are by nature akin $(o i k e i o i)^{2}$. I here trace the main lines of the dialogue that this passage initiated. This will help to explain the tensions in Stoic cosmopolitan thought as it is presented in Cicero.

The passage of time has submerged much of the thought of the post-Aristotelian Peripatetics and the Stoics. Even the most conservative scholarly account of that history must be taken as somewhat speculative and provisional. Just one additional fragment or testimony could involve major changes in the story we tell.

It is not always the case that neglected evidence is found in texts contemporary or subsequent to the figures we are studying. If we know that an earlier text was a central object of study and that it makes points directly counter to the philosophical teachings of a later figure, it is a fair guess that the later figure would have responded to the earlier. This is even more likely if the earlier text employs distinctive vocabulary or concepts which the later author employs. The historian of philosophy will then read the surviving evidence as potentially forming part of such a response.

This is an avenue for the study of Stoic cosmopolitanism. Each later Stoic develops and responds to the thoughts of earlier Stoics, all in some way furthering the project of the founder of their school, Zeno of Cittium. Zeno's key political work was his Republic, which, according to Plutarch (On Stoic Self-Contradictions 134f) was written as a response to the Republic of Plato. Later Stoic political philosophy had one eye on this work and another on its Platonic model. ${ }^{3}$

I suggest that Zeno, his predecessor Theophrastus, and his follower Chrysippus are responding in different ways to a notorious passage in

2 On the prephilosophical antecedents of the term oikeion, see Pembroke 1971, 115. The origin of the term is oikos, "house" or "household", from which to oikeion refers to a thing that belongs to the house, one's property. From this the term came to be applied to that which belongs to one, in any sense of "belongs", and came to be commonly contrasted with allotrios.

3 Cf. Vogt 2008, 66: "Plato's Republic looms large in the background of Hellenistic discussions (and in the minds of modern scholars), and it is almost inevitable that one tries to understand the cosmic city by comparing it with Plato's ideal city". 
which Socrates asserts that while Greeks are by nature friends, Greeks and barbarians are by nature enemies. Socrates explains the moral relevance of the distinction between Greek and barbarian by first distinguishing between the oikeios (akin) and sungenes (related) on the one hand, and the othneios (foreign) and allotrios (alien) on the other. He then asserts that "the Greek itself is oikeios and sungenes in respect to itself" while this genos is othneion and allotrion in respect to the barbarian genos (470b-c). Oikeios and allotrios are loaded words in Stoic thought. Hellenistic philosophers were rarely nuanced historians of philosophy; it is likely that middle and later Stoics would have read Plato as employing the words in the senses that they later took on. ${ }^{4}$ An account of other-regarding morality that takes the notion of to oikeion to be central, and argues that it ought to be extended to all humanity, would be presented as a corrective to the views of the Republic.

I turn to the Platonic passage in question.

In Republic Books 2-4, Socrates argues that the culture of a society, its literature and laws, are responsible for conventions and beliefs concerning what is one's own (to oikeion). When what is one's own is private, not shared by others within the community, there is the danger that when one pursues what is one's own, he or she will act in a manner detrimental to the unity and health of the community. It is for this reason that Socrates mandates that the guardians share possessions, spouses, and children as common to all: "Isn't it the case that, when they have a single belief concerning what belongs to one (tou oikeiou), they all strain for the same thing and to the extent possible they all have the same feelings of both pleasure and pain?"5 Accordingly, the political structure, culture, and religion of the best society, Kallipolis, ought to be organized in such a manner as to minimize the gap between private and public goods. The most radical aspect of Socrates' proposal is, of course, the abolition of the nuclear family for the ruling class. The intended effect is to bind the rulers together so that each will be akin (oikeios) to each other:

"So, concerning the rulers in the other cities, can you say whether any is in a position to address one fellow ruler as akin (oikeios) but another as alien (allotrios)?"

"Many do".

"Now doesn't he think of his kin as his own, and talks about him in that way, but he thinks of and talks about the alien as not his own?"

"That's how it is".

"But what about your guardians? Is there any of them who would be in a position to consider any of his or her fellow guardians as alien, or address him or her as such?"

As did later Academics; see Shorey 1929.

Rep. 5 464C3-5. Except where otherwise noted, all translations are mine. 
"In no way", he said. "For whomever he or she should meet, this one will think that he is meeting a brother or sister father or mother or son or daughter or their descendents or forbears". (Rep. 463B10-C7)

This belief will be especially important in regard to conduct in war, which often requires great sacrifice to oneself and one's immediate family in pursuit of the common good. Those who consider the fellow soldiers as kin will be much more likely to sacrifice their private good for the sake of the welfare of others.

This is why Socrates explicitly turns to the matter of the conduct of the army of Kallipolis at time of war:

"I say that the Greek tribe (to hellenikon genos) is itself akin and related (oikeion kai sungenes) to itself, but is enemy and alien to the barbarian tribe".

"You are right", he said.

"Therefore when Greeks fight against barbarians and barbarians against Greeks, we will say that they are even enemies by nature, and this enmity must be called war. But when Greeks do such a thing to Greeks, they are $\langle$ still $\rangle$ friends by nature, and Greece, in such a condition is sick and in contention, and this sort of enmity must be called contention (stasin)"....

"And won't they be lovers of Greeks? And won't they think that Greece belongs to them (oikeian) and won't the other 〈Greeks〉 share their holy places?"

"Very much so".

"Then, since they are kin (oikeious), won't they consider any dispute as contention and not give it the name 'war' (polemon)"?

"They won't do that".

"So they will have their disputes as befits those who will be reconciled?"

"Surely". (Rep. 470c1-471a5)

Socrates asserts that among fellow Greeks there is no war, strictly speaking, as they are kin and related. Conflict among the Greeks is rather contention within a single people. True war, in contrast, is between those who are allotrioi, by nature enemies: Greeks and barbarians. Socrates lays out the practical implications of this distinction. In the case of contention, military strategy ought to be mild, for following the curative conflict, friendship among the Greeks will again prevail. In contrast, in the case of true war, no quarter is to be given (471A).

To be "related" (sungeness) is to have the same source or origin; it is to have come to be (genesthai) together. Thus the term is employed to refer those of the same family. The term "akin", oikeios, is likewise not yet a technical term, as it is for the Stoics. To be oikeios is to dwell (oikoun) with another, to be part of one's household, to be in one's house (oikos); thus it can refer to what belongs to one in a private or intimate way. The thing or person who is your kin, oikeios to you, can be said to be your own.

Socrates' words are very much in line with the conventional political thought of the day. When Euthyphro defends his decision to indict his father for murder of a slave, he insists that the pollution brought about by 
a murderer is the same whether the one murdered is oikeios or allotrios (Euthy. 4b), implying that the response of his friends and family (apparently shared by Socrates), that such a charge should only be brought on behalf of one who is oikeios, is an arbitrary limitation on the demands of justice. The point that we ought to treat the oikeioi in a manner different from the allotrioi is also evidenced by texts such as Isocrates' Panegyricus, an exhortation for the Greeks to unite and take a common stand against hoi barbaroi, the non-Greeks. ${ }^{6}$ Perhaps this is why Glaucon and Adeimantus soon tire of them, and want Socrates to hurry and get to the juicier discussion of sex. But the passage takes on philosophical complexity when we consider it in light of other philosophical developments of the Republic. For the Republic itself presents an account of human nature according to which the distinction between Greek and non-Greek is not rooted in nature, and the most important human philosophical activities can be shared by the properly trained natural elite of any time, place, and gender. Reason is the core of the human soul, and one's true good lies in reason's engaging in philosophical inquiry and its goal, the apprehension of Forms. Republic 557C makes clear that within a democracy there are souls corresponding to all forms of government; hence outside of Kallipolis it is the only form of government in which philosophy is possible. Insofar as democracy is a distinctively Greek mode of government, the highest human good is found among the Greeks alone. But this is a contingent fact; nowhere is Greek cultural or genetic identity given as a precondition for philosophical inquiry. Further, as Statesman 262D makes explicit, barbarians do not constitute a true genus. So how are we to understand Socrates' remarks concerning the natural relations between Greeks and barbarians?

If we take everything that Socrates says in a dialogue to be an expression of Plato's views at the time of its writing, we must write this passage off as evidence of Plato's unfortunate unreflective acceptance of the prejudices of his time and place; on this view, the Statesman marks a philosophical advance. It could well be that this is how Hellenistic philosophers took the passage in question. But when reading Plato we ought to take into account who is talking, to whom he or she is speaking, and the existential and pedagogical circumstances of the interlocutors. I must here bypass the debate concerning how to read a Platonic dialogue, and only indicate that I do not take the passage in question to be intended as a serious element of Plato's philosophy of human nature. I do so not only because it sits ill with other accounts of the nature of the human soul and its capacities, as indicated above, but also because Socrates himself is explicit that there are sometimes good reasons for one who is wise (like him-

6 For an especially stark parallel with the Republic, consider 4 158, phuseiolemikos pros autous ekhomen, "by nature we are disposed to make war with them". 
self) to say false things to those, like Glaucon and Adeimantus, who have not yet achieved true wisdom. Such falsehoods are said to be required as a kind of medicine, as a means to achieve certain necessary goals. The most famous example of this is the "noble lie" or "myth of the metals" that closes Book 3. The unity of the polis demands that its citizens not seek to maximize their private good. The true, highest private good is also a public good: wisdom. But those not yet capable of wisdom, or even of appreciating the concept of wisdom, must come to identify their private good with a public good by means of the religious stories that are largely responsible for their moral training. The noble lie of the Republic does this, in part, by relating the falsehood that the first citizens of the city sprang from the very ground that they inhabit $(414 \mathrm{D}-\mathrm{E})$. A similar myth of autochthony is also presented in Isocrates' Panegyricus, which is roughly contemporaneous with the Republic:

[W] did not become dwellers in this land by driving others out of it, nor by finding it uninhabited, nor by coming together here a motley horde composed of many races; but we are of a lineage so noble and so pure that throughout our history we have continued in possession of the very land which gave us birth, since we are sprung from its very soil and are able to address our city by the very names which we apply to our nearest kin (tous oikeiotatous); for we alone of all the Hellenes have the right to call our city at once nurse and fatherland and mother. $(424-5)^{7}$

According to Isocrates, the Athenians are oikeioi in regard to their land and to each other; the barbarians lack this connection to either the land or the Athenians, which is why the Athenians must band together and fight them in defense of their own. Isocrates does not hint that such talk is not to be taken seriously, but Socrates explicitly calls the talk of autochthony a necessary falsehood. His talk of the natural relations between Greeks and barbarians might need to be interpreted in the same way.

Why would such a tale need to be told to those who have not yet achieved a philosophical level of morality, such as the guardians in training, as well as Glaucon and Adeimantus, to whom Socrates is speaking?

In Book 2, Socrates takes wars to have as their origin the need to appropriate land, in order to satisfy the city's unnecessary desires for the acquisition of wealth (374D-E). But as Socrates develops his city in speech, he purges it of all desires for material goods not required for bodily health. Socrates' city will never engage in an offensive war; all wars will be defensive. It follows that it would be reasonable for the citizens of the best city to treat Greek invaders differently from non-Greek invaders. The Greeks who might invade will be geographical neighbors, with whom some interaction will be unavoidable. Were the spirit of the soldiers to be inflamed by their being trained to think of these neighbors as unalterable

7 Tr. from Norlin 1928. 
enemies, offensive wars might well break out, motivated by the craving for retribution. Nothing would be gained from such conflict, and much could be lost. On the other hand, nothing is said in the Republic about citizens' travels abroad. The city is self-sufficient in regard to necessary material goods, so there will be no need for trade. Nor will there be the sorts of trips abroad for the sake of wisdom and cross-cultural understanding that are envisaged in the Laws (951A-952C); Kallipolis is set up as administered by the those who have already attained the pinnacle of the understanding of political things. Hence non-Greeks would be encountered only when they are attacking the homeland. So in this case, there would be no danger, and much advantage, in having the warriors' passions permanently inflamed against them. The philosophers, who design the educational system behind the warriors' moral training, would know better than to think non-Greeks alien by nature, and would realize that the best society, and the best life that it makes possible, are in principle available to all. $\mathrm{He}$ or she would realize that Greeks and non-Greeks alike could join together to seek truth in philosophical friendship. Here, as elsewhere in Plato, we see a distinction between the conventional morality appropriate for the multitude and the philosophic morality appropriate for the few. Conventional morality, as Plato understands it, need not involve cosmopolitan principles.

Hellenistic political philosophers responded to these points, and to each other, with Socrates' words in mind.

Aristotle had remarked in an offhand way that while like tend to be friends with like, which is why friendship is found most between parents and children, we see in our travels that every human being is oikeios and is accordingly a friend to one another $\left(\begin{array}{llll}E N & 1 & 1155 a 19-22\end{array}\right)$. This may well have been intended as a correction to Plato, but it was not the opportunity for sustained philosophical reflection. It was Aristotle's student Theophrastus who first presented explicit arguments against restricting justice to fellow Greeks. The relevant passage is a quotation, of uncertain extent, found in Porphyry's de Abstinentia 3 25:

But Theophrastus has made use of an argument like the following. We say that those with the same progenitors (I mean, the same father and mother) are by nature kin (oikeious) to one another. And for this reason we think that those who are descended from the same distant ancestors are kin to one another, as are fellow citizens, since they have in common their land and mutual relations. For we do not judge such people to be kin to each other on the grounds that they are descended from the same people, unless the very founders of the clan are their first forebears. For just as we think that a Greek is kin and family to a Greek, and a barbarian to 
a barbarian ${ }^{8}$, so we say that every human being is kin and family to every other. We say this for one of two reasons. First, all people have the same forebears. Second, all people have in common their food, culture, and membership in the same kind ...9

Theophrastus here argues against Plato. Plato had said that Greeks and aliens are not oikeioi. He did not give reasons, but the myth of the metals that concludes Book 3 takes kinship to result from the same physical origins, which suggests that Greeks and barbarians are alien in respect to each other because they have different physical origins. Different kinds of people come from different areas of the earth, and hence have a natural antipathy. Given the sensitivity of both Plato and Aristotle to the importance of cultural conditioning in molding character and common beliefs, Theophrastus would likely have also been familiar with the suggestion that Greeks and non-Greeks have a deep and lasting antipathy on account of opposed cultures. In asserting that Greeks and non-Greeks share both land and culture, Theophrastus argues against both reasons, explicit and implicit, for thinking that the two groups are not oikeioi. He then extends the line of reasoning to other animals. It is not clear how far the paraphrase of Theophrastus continues, and whether Theophrastus himself would endorse this or any ethical conclusion from his argument. But Porphyry shows how this line of reasoning can be extended. Just as it is unjust to do injury to any other human being who does not pose direct harm, no matter what his or her geographic origin or culture, so too it is unjust to do injury to animals; hence we should not kill them to eat them. Isocrates, Plato, and Aristotle, as we have seen, take there to be certain ethical obligations owed to those with whom we are oikeioi. Theophrastus argues that other animals are oikeioi in respect to us. ${ }^{10}$ Porphyry (if not Theophrastus) then draws the conclusion that we should do them no harm.

Within de Abstinentia Porphyry presents a second extract from Theophrastus which explicitly links the relation of being oikeios with moral obligation. Theophrastus says we are justified in punishing evil-doers, even though they are oikeioi in respect to us, on the grounds that evil doers do us harm ( $D A 222)$. Theophrastus is saying that prima facie, it is wrong to harm those who are oikeioi in respect to us, but this prohibition can be

8 As Darrell Dobbs pointed out to me, the notion that barbarians are kin and family to barbarians is odd, given the insight of Plato's Statesman that barbarians do not comprise a single determinate kind. Perhaps "barbarian" here simply means "Persian" or the like.

9 Tr. O. Goldin and F. Romer.

10 Neither Aristotle nor Theophratus elsewhere employ the term oikeios to refer to biological affinity or resemblance; hence I suspect that Theophrastus, like Porphyry, is using the term here to make a point concerning the moral treatment of animals. 
overridden by other factors. Theophrastus is not making a mere sociological point here, about what people do; he is making an ethical point, saying what people should do. Pohlenz and Brink ${ }^{11}$ are right to caution us against ascribing to Theophrastus here a Stoic-style cosmopolitan political philosophy based on the thesis that every human being is oikeios in regard to every other human being. To be sure, the notion of being oikeios is left unclear, and we do not know what sort of community Theophrastus took to hold among the oikeioi. Nor do we know exactly what is the nature of the moral obligation that holds among members of such a community. Perhaps Theophrastus is here appealing to the conventional untheoretical belief that blood is thicker than water, and that, except under exceptional circumstances, relatives ought to take care of each other. But it is not insignificant that he uses the term oikeios, which encompasses more than family ties and extends to any other that one can in some sense call one's own. The two passages from Theophrastus, taken together, provide raw materials for a Peripatetic argument for a cosmopolitan conclusion: there are certain core moral obligations to others that extend to everyone, regardless of political or ethnic identification. The boundaries of the city or tribe are not moral boundaries. ${ }^{12}$

11 Pohlenz 1940, 13; Brink 1956.

12 I have restricted myself to Porphyry's Abst. in reconstructing his theory of social ethics. Scholars have also mined Stobaeus, Anthol. 116-128 (Wachsmuth), a summary of Peripatetic ethics that derives from Arius Didymus, for evidence concerning Theophrastus' ethical theory. Although this passage does include material that extends the obligations of justice from one's kin to all humanity (120-2), I do not appeal to it, since it remains controversial how much of this material has its origin in Theophrastus and how much in the Stoics. If we were to ascribe this material to Theophrastus, my conclusions concerning the contribution of Theophrastus to Stoic cosmopolitan thought would need to be supplemented by the observation that Theophrastus was systematic in his expansion of the relation of being oikeios to those outside of one's immediate circle. For Arius relates that the Peripatetics discuss how people love immediate family, spouses, relatives and other kin (oikeioi), fellow citizens, those of the same people (ethnos), those of the same race (phulon), and all human beings. The kinds of human relatedness can be laid out schematically in this way because we have by nature different relationships of being oikeios (ekhein gar ek phuseōs hèmas kai pros toutous tinas oikeiotètas). Thus Görgemanns 1983, 186, integrating material from Porphyry and Arius, writes of Theophrastus "The main innovation is an application of classificatory procedures, which result in an unusually comprehensive view of moral relations, including animals". Below, I discuss how Chrysippus extends the relation of being oikeios to one's own body and offspring to all rational beings on account of his metaphysical holism, according to which all rational beings are part of a greater logos that permeates and governs the whole cosmos. It might be argued that if I am right, Arius' summary must predate Chrysippus, since there is no such appeal to cosmic holism in Arius. But if Arius is giving a late Peripatetic account which has absorbed Chrysippean features, it stands to reason that it 
While Theophrastus' answer to Plato is to challenge him concerning the moral relevance of place of origin and to suggest that similarities of culture are more striking than differences, the Stoic response has a different source. Its root is Zeno's Republic. This Republic, like Plato's, lays out the principles for an ideal community. But Zeno rejects the Platonic elitist premise that human beings necessarily have different kinds of souls, and that not everyone is capable of philosophical wisdom. In his view, all mature human beings are rational, and are in principle capable of rational choice. ${ }^{13}$ Thus, for Zeno there is in principle no reason why there cannot be a polis of sages-as in Plato's Republic, the proposed arrangement is intended to be difficult and unlikely, but not impossible. In the case of both Republics, it is unclear exactly what the purpose of the political reforms being proposed is. Are they meant as programs of political reform, as mere steps in an argument concerning the psychology of the individual human being, or as constituting a way of analyzing and diagnosing the deficiencies in existing societies? ${ }^{14}$ One thing is clear: a sage, whose every action is in accordance with the demands of justice, would not follow irra-

would avoid pointing to Chrysippus' own theoretical justification for the extension, since a metaphysical holism of the sort found in Chrysippus is alien to mainstream Peripatetic thought.

13 According to Plato's Republic, all human souls have reason, but for most human beings, the irrational elements of the soul (thumos and desire) are too strong to be fully mastered or harmonized by reason. Only a few, those naturally capable of philosophy, are such as to have their action entirely guided by reason. Plutarch, On Moral Virtue 441a6-11 indicates that in contrast, Zeno, like the middle Stoics, held that the humans act by virtue of a unified rational soul, so that all moral error comes about by virtue of misreasoning. (On this see Long and Sedley 1987, vol. 1, 422.)

14 Schofield 1999 understands the work as utopian, with Plato's Republic taken as a model. According to him, the unique features of the society that Zeno describes constitute those social institutions that would make possible the best society, as Zeno describes it. In contrast, Sellars 2007 understands Zeno to be advocating a program of reform of only particular lives, which, if engaged in by a number of individuals, would lead to there being a number of sages. On his account, the account of the ideal polis that Zeno presented tells of what society would be like if such sages were to find each other and to live together. A third possibility is that of Vogt 2008, 65-110, according to whom Zeno's society is the world as it is now, of which only sages are citizens in the strictest sense; he is describing how the sage acts, anywhere, anytime. This issue does not have bearing on the matter before us. Whether he thinks that a way of life that makes no moral distinctions in regard to geographical, biological, or cultural origins is dictated by laws resulting from social reform, or that it results from the independent attainment of personal wisdom, Zeno holds that such a way of life is in conformity with reason. 
tional laws or customs. His or her code would be that of philosophical morality alone.

So what is philosophical morality for Zeno? He takes the common recognition of rational law as being the relevant tie at the root of moral obligation. As Plutarch reports:

The much admired Republic of Zeno ... is aimed at this one main point, that our household arrangements (oikomen) should not be based on cities or parishes, each one marked out by its own legal system, but we should regard all men as our fellow-citizens and local residents, and there should be one way of life and order (kosmos), like that of a herd grazing together and nurtured by a common law. ( $O n$ the Fortune of Alexander 329a-b; LS 67A, tr. LS)

Diogenes Laertius explains the basis of Zeno's community of sages, and of the moral obligation to each other that they are to recognize: "[A]ll who are not virtuous are foes, enemies, slaves and estranged (allotrious) from one another, including parents and children, brothers and brothers, relations and relations (oikeious oikeionn)" (DL 7 32, LS 67B, tr. LS). Zeno's language here echoes the Republic. ${ }^{15} \mathrm{He}$ agrees with Plato in discounting the moral importance of biological family relations. But he rejects the Socrates' teaching that being fellow-members of a particular community involves special obligations. The true basis of the relationship of being oikeios and the moral obligations that it entails, is sameness in wisdom, not genes or geography. Presumably this is because all of the wise see what living in agreement with the divine reason requires, and will be of one mind in pursuing it. All of them will see that the communities commonly recognized as such are not in accordance with nature. They have no ethical relevance, and cannot claim the loyalty of the sage. It is possible that Zeno recognized that Plato's indication of an ethical significance of the distinction between Greek and barbarian is a kind of noble lie, necessary for the civic education of the non-philosophical majority. But such a lie would not be necessary in Zeno's solitary sage, any more than it would be for his community of sages.

We turn now to Chrysippus. Although the evidence for his views on our ethical relation to foreigners is not as full as we might like, all of the pieces were in place to allow Chrysippus to develop Zeno's political theory to

15 According to Vogt 2008, 109, Zeno's use of the terms oikeios and allotrios is more than an echo of Plato; the terms already have the technical sense that they have in the context of the theory of oikeiosis. 
argue for Theophrastus' conclusions. While Theophrastus argued for cosmopolitan ethical obligations on the basis of a theoretically thin notion of the oikeios, Chrysippus could well have grounded a cosmopolitan argument on the metaphysical and ethical theories to which we know he subscribed. ${ }^{16}$

Diogenes Laertius begins his account of the Stoic ethical end by explaining Chrysippus' notion of oikeiōsis:

They [the Stoics] say that an animal has self-preservation as the object of its first impulse, since nature from the beginning appropriates it, as Chrysippus says in his On Ends Book 1. The first thing appropriate to every animal, he says, is its own constitution and the consciousness of this. For nature was not likely to alienate the animal itself, or to make it and then neither alienate it nor appropriate it. So it remains to say that in constituting the animal, nature appropriated it to itself. (7 85; LS 57A, tr. LS)

For Chrysippus and the Stoics who followed him, nature is the level of organization common to all living things. It is by nature that a living organism is unified, in such a way that the whole organism responds as it should to localized needs and stimuli. This occurs by virtue of the pervading pneuma which teleologically guides an organism in the manner fitting for it. In the case of animals, this involves perception or awareness. For when something external to one is sensed, the pneuma is set in motion, and this same pneuma is an embodiment of the divine logos by which all things are ordered to the best. Within the organism, this motion of the pneuma leads the organism to pursue a sensed object that is in accordance with its teleology, and to avoid one that is not. This is the process by which a threatened injury to a part of an animal's own body is avoided. In this case, the threatened part of the body, which is animated by one's own pneuma, is in a sense recognized by that same pneuma as so animated. This awareness of an organism that a part is oikeion, that is, that it is one's own, comes through a process called oikeiosis. ${ }^{17}$ Diogenes Laertius explains how oikeiosis results in a bodily motion, to or away from what is perceived. The motion of the pneuma responsible for this bodily motion is called an impulse (hormè). In the case of rational animals, impulse is the result of a

16 Vogt 2008, 100, n. 70 suggests that her reconstruction of Zeno's thought points to the conclusion that Zeno himself had at least the framework for the theory of oikeiosis. If she is right, the developments that I find in Chrysippus can be traced back to Zeno.

17 The traditional translation is "appropriation". Another translation, felicitous in some contexts, might be "owning up" (Darell Dobbs, in personal communication). On the prephilosophical antecedents of this term, see Kerferd 1972. Dirlmeier 1937 mistakenly takes the evidence concerning the ethical importance that Theophrastus gave the relationship of being oikeios as evidence that he employed the notion of oikeiosis in his moral psychology. See Pohlenz 1940, 1-81; Pembroke 1971, 134-137. 
rational process of oikeiosis, in which the recognition of what is one's own and what is not comes about through rational thinking. Such rational thinking results in bodily motion on account of an inner process much more complicated than that of other animals. There is an inner representation, called a phantasia, of some state of affairs, as either to be chosen or avoided. As rational animals, human beings may either assent to the phantasia, which leads to the impulse and action in accordance with it, or withhold assent. When we assent to a phantasia as we should, and act accordingly, we act ethically.

So understood, Stoic ethics is a form of eudaimonism, for the human good is action in accordance with our teleology as individuals. Here, as in the case of other Greek eudaimonistic theories, the problem arises as to how to account for other-regarding obligations, such as those of justice.

The evidence is clear that Chrysippus extended his analysis of ethical action to other-regarding actions. An exasperated Plutarch writes:

Why then again for heaven's sake in every book on physics and ethics does he [Chrysippus] weary us to death in writing that we have an appropriate disposition (oikeiosthai) relative to ourselves as soon as we are born and to our parts and our offspring? In his On Justice Book 1 he says that even the beasts have an appropriate disposition relative to their offspring in harmony with their needs, except for fish, since their spawn is nurtured through itself. (de Repug. 1038b; LS 57E, tr. LS)

Just as it is oikeiosis that allows an animal to act in her own interest, so this process is responsible for her acting in the interest of her offspring. ${ }^{18}$ Plutarch tells us that Chrysippus makes this point towards the beginning of his book On Justice, a strong indication that oikeiosis towards others is at the root of all obligations of justice. ${ }^{19}$ If I recognize that I ought to act

18 We have seen in DL 7.85, quoted above, that oikeiōis in regard to oneself is prior to that in regard to others. A major question is what sort of priority this is. It is, at the very least, logical priority. The recognition of others as one's own, on the basis of seeing that others are the same, in some relevant way (whether as fellow parts of a whole, or as having similar individual natures) has as its logical precondition an awareness of oneself. But there is much evidence that for many Stoics, oikeiosis in regard to oneself is a temporal starting point for the recognition of others as oikeioi; it is the start of a psychological process by which one others as one's own. Cicero $D F$ 3.65 is evidence that this process was discussed by Antiochus; it may well date back to the Middle Stoa, but the evidence is not clear. See Pembroke 1971, 123-5.

19 See Pembroke 1971, 123. Similarly Porphyry Abst. 319 relates that the "followers of Zeno" made oikeiosis the arkhe (which here could refer to either a temporal starting point or [logical] principle) of justice). (This is not decisive evidence on its own. Pembroke 1971, 122 thinks it likely that Porphyry has in mind Chrysippus, as well as other Stoics, but cautions that Chrysippus need not have said that one's oikeiosis toward others is the arkhe of justice. He could simply have meant that the process by which we become aware of our own rationality, as constitutive of our virtue, is the origin of the process by which we gain a virtue, such as justice.) Similarly in $D F 3$ 
in a certain way towards you, it is only by virtue of my rationally seeing that you are oikeios in respect to me. Just as my thumb is my own (for which reason I take due care of it) so a fellow human being is in some sense my own. ${ }^{20}$ We do not know exactly what sense this is, nor who exactly are those others with whom Chrysippus thinks one stands in the relation of being oikeios. Could Chrysippus have followed Zeno in saying that only the wise are oikeioi in relation to the wise? The unwelcome consequence of this would be to say that there are obligations of justice only among the wise.

Several scholars have suggested that Chrysippus did not integrate his account of oikeiosis in regard to the individual and his or her offspring, and that of oikeiosis towards more distant individuals. ${ }^{21}$ They suggest Stoics went back to Theophrastus to fill the gap ${ }^{22}$ or simply reveal to us the gap by a discontinuity in their own accounts. ${ }^{23}$ Others suggest that, although the Stoics stress that our obligations have an instinctual basis, as in the case of Kant, it is the demands of reason (which dictates what virtuous action is) not the ways in which other moral objects (rational beings) are related to the moral subject, that requires this extension of the bonds of justice to all rational beings. ${ }^{24}$ But this would make the relation of being oikeios theoretically irrelevant to Chrysippus' theory of justice, which it clearly is not. I think this unlikely. As we have seen, Chrysippus began his book On Justice with an account of how the individual animal is teleologi-

62-3 Cicero attributes to "the Stoics" a similar argument: just as Nature teleologically designs the individual human being to produce and take care of his or her children, so we are designed to take care of all human beings, and this is the origin of the psychological bond among all human beings that Cicero calls commendatio. The link to justice is made explicit at DF 67. On this passage (LS 57F) see Pohlenz 1940, 135; Pembroke 1971, 121-3; Long and Sedley 1987, vol. 1, 350-4; and Engberg-Pederson 1990, 122-6 (who, in line with his general account of oikeiosis downplays the importance of a cosmic teleology in Stoic moral theory). See also Stobaeus 2 94, 7 20 and Porphyry Abst. 3 26.9-10.

20 Thus far I follow the argument sketched by G. Striker in "The role of oikeiōsis in Stoic ethics" (in Striker 1996, 293f.): “[R] easoning ... shows us that we are made to live in communities, and that the attitudes of care and respect should be extended to comprise not only our family and friends, but mankind in general". However, she does not discuss how the concern of individual for the community is actually a kind of self concern, since the community (whether local or worldwide) is a true whole of which the individual is a part. Nor does she discuss how Chrysippus' thought develops as a response to earlier Greek debate on who are those to whom the obligations of justice extend.

21 Pembroke 1971, 123-5 notes the conceptual gap, but does not seem to think that the Stoics recognized it.

22 See Brink 1956, 137f.; Görgemanns 1983, $182 \mathrm{f}$.

23 See Inwood 1983.

24 Annas 1993, 265-7. 
cally organized in such a way that it acts in the interest of itself as a whole, as well as its offspring. The title indicates that Chrysippus went on to discuss more encompassing demands of justice. I doubt that Chrysippus could have jumped from the one topic to the other with no attempt to bridge the two. I suggest that Chrysippus developed his theory of justice by extending his account of the teleological metaphysics of the parts of the organism in regard to the whole, and the teleological metaphysics of the parents in regard to the whole family, to the teleological metaphysics of the individual rational being in regard to the whole rational cosmos. ${ }^{25}$ Chrysippus was the first Stoic for whom there is clear evidence of following Plato in understanding the whole cosmos as a single living thing. ${ }^{26}$ All parts of the universe, therefore, are oikeia with each other. This is not to say that a rational being would recognize obligations of justice extending towards everything. For we recall that oikeiosis is the rational recognition of what is one's concern, given the teleological organization of the whole of which one is a part. Chrysippus is convinced that plants and non-rational animals are for the sake of rational animals (Plutarch de Repug. 1044d, LS 54O; Porphyry Abst. 320 1, LS 54P). So the cosmos, considered as a rational unity, can be for the sake of all of the welfare of all of the particular rational beings that make it up. There is strong evidence that Chrysippus gave this a political formulation: the logos that animates the whole is like a ruler, and the particular human beings are like subjects,

25 I am here following up on some remarks made by Cooper 1995, on how Chrysippus' ethics is based on his teleological holistic metaphysics. Cooper cites DL 7.88, according to which the end of the individual human is to live in accordance with the nature of the whole, and Plutarch, de Repug 1035c-d (SVF 3 68, LS 60A): "Again in his Physical Postulates he [Chrysippus] says 'There is no other or more appropriate way of approaching the theory of good and bad things or the virtues or happiness than from universal nature and from the administration of the world'. And later: 'For the theory of good and bad things must be attached to these, since there is no other starting-point or reference for them that is better, and physical speculation is to be adopted for no other purpose than for the differentiation of good and bad things" (tr. LS). A similar strategy is taken by Vogt 2008, 107f. The appeal to the notion of the cosmos as an organism, of which all people are integral parts, as a support to a cosmopolitan ethics, is seem most clearly and explicitly in Marcus Aurelius, Meditations 7.13, on which see Nussbaum et al. 1996, 10 and 1997, 10. In contrast, Nussbaum 1997, 7-8 attributes to the Middle Stoa a quasi-Kantian argument according to which cosmopolitan ideals are to be pursued since "the dignity of human reason is worthy of respect wherever it is found". I do not find such an argument supported by the relevant texts. In the text cited by Nussbaum (Seneca, Ep. Mor. 41) Seneca tells us that it is the perfected human soul of the sage that is inherently worthy of respect. Other human beings are to be treated well not on account of intrinsic merit, but on account of the kinship one has towards them, as a result of the teleological role they play in regard to society, and cosmos, as a whole.

See the evidence collected in LS 54. 
united under divine rule as fellow citizens in one city. ${ }^{27}$ But there is no evidence that Chrysippus said that other living things are only for the sake of only the sages, those who have perfected their rationality. For, however imperfectly developed they might be, all rational beings are, as rational, parts of the unitary reason that both directs the cosmos and is its ultimate purpose. To act in accordance with the logos of the whole universe, then, is to act in the general interest of rational beings. It is this which one comes to recognize as one learns to more accurately identify that which is one's own (oikeios), in whose interest one ought to act. It follows that it is by oikeiosis that rational beings recognize obligations of justice extending towards all other rational beings, their fellow citizens in the cosmos. ${ }^{28} \mathrm{Ze}$ no's notion of negative cosmopolitanism, according to which the special obligations of particular communities would be abolished in a community of sages, is replaced by a positive cosmopolitanism: whether we realize it or not, we are citizens in a world community.

The evidence is silent concerning exactly what obligations Chrysippus took this citizenship to involve. One crucial piece of evidence in the famous fragment of Hierocles (Stobaeus 4 671,7-673,11; LS 57G) in which our place within the human community is described as being like the center or a number of concentric circles, on which lie other human beings. The circles closest to us contain immediate family and loved ones, those farther include those of the same tribe or community, and the farthest include strangers. Hierocles tells us that we are obliged to contract the circles, treating those within a circle as we would treat those within the next circle inward. The logical result of extending this to the utmost would be total impartiality, as all of the circles would necessarily coincide with the center. ${ }^{29}$ The obligation to so contract the circles has a natural basis, the fact that human beings are the sort that are prone to fellowship

27 The evidence for attributing this view to Chrysippus in marshaled and evaluated in Schofield 1999, 57-92. See Bees 2004, 177-99 for evidence that the view that the cosmos is a world community as well as a world organism, as expressed in Cicero ND 2 derives from the Middle Stoa if not earlier.

28 Pembroke 1971, 123-132 argues that Chrysippus did not extend the moral obligations of justice beyond others (family and friends) with whom one already has special, particular relations. He supports this on the grounds that political structures by which one comes into contact with those outside of such particular relations are external to a moral agent, and hence cannot be governed by personal morality. But this downplays the extent to which Chrysippus was committed to a cosmic teleology, which comprehends conventional political associations, and creates a fissure between philosophical and conventional justice in Chrysippus for which there is no direct evidence. This is in contrast to Zeno, whose antinomianism was often an object of apology among later Stoics.

29 On the contraction of the circles as mandated by logic, and not as resultant from the normal path of psychological development, see Pembroke 1971, 125. 
(11 14-18, LS 57D)..$^{30}$ But, just as Mill insisted that our natural tendency to be happy when others are happy needs to be trained to extend beyond those in our immediate sphere, Hierocles describes the contraction of the circles of human relationships as a difficult work in progress. The ethical ideal of universal impartiality may well have been part and parcel of orthodox middle Stoicism, and Chrysippus may well have thought such impartiality ethically mandated, and as the ethic standard met by the sage. But Hierocles is giving advice to those for whom the circles maintain distinct identities, still at distinct distances from the center. He seems to be admitting that, although we all have equal standing as moral objects, before one reaches the level of a sage it takes intellectual work to see that this is so, so it is necessary that even those making moral progress treat some fellow rational beings as belonging to one in a more basic way than do others.

\section{6}

How far does the cosmopolitanism of the Middle Stoa extend? Does it require that one treat all human beings impartially, since they are all equal as fellow members of the world community? Or is it ethically legitimate to give special consideration to fellow members of a family, tribe, or political community, in the conventional sense? For one, like a Stoic, who sees

30 Significantly, for the main theme of this paper, in the Hierocles papyrus the lone surviving word that follows this passage is thaumastiotaton, "most surprising", which scholars speculate refers to the fraternization of enemy soldiers: see Pembroke 1971, 127, and Long and Sedley 1987, vol. 2, 345. (It is unlikely that this remark was intended to be restricted to what occurs when the combatants are fellow Greeks.) The view that human beings are fundamentally social animals is well attested in Middle Stoicism. See Stobaeus 2 109, 16 (SVF 3 686, LS 67W). On this see Pembroke $1971,127 \mathrm{f}$., who takes the grounding of justice on fellow-feeling to be a "simplistic" "one-step" view which, if true, would entail the obviously false conclusion that all human beings by nature treat each other with perfect justice and impartiality. But this does not follow. The existence of some natural love and fellow-feeling, grounded on the fact that all human beings are oikeioi in regard to each other, does not entail that such love be felt equally to all. For, from the point of view of the part (the individual human being), as opposed to the whole (the cosmos as a whole), the self is the most oikeios, after that family, and so on, proceeding outward through the sequence of Hierocles' circles. It is only to be expected that people, as parts, will maintain the point of view of a part, and deal with those in the interior circles in a way that is to the detriment of those in the more outward circles. That said, Marcus Aurelius, at any rate, did at least entertain such a "one-step" view, in taking the relation of the individual to the whole cosmos to be that of the limb or head to the human body. See Med. 8.34. As Darrell Dobbs has pointed out to me, the remote ancestor of this organic understanding of political community as like the unity of the human body is Plato, Rep. 462c11-d5. 
the world as a single polis, special obligations towards members of conventional political communities would be recognized only insofar as the existence of such communities, and the expectations they raise for their members, are themselves in accordance with the rational ordering of the whole. The evidence is silent as to whether Chrysippus understood conventional ethical norms as mandated by justice in this way. But this is just the sort of move we see in the thought of Panaetius, as it has come down to us via Cicero in his de Officiis.

Although he never identifies himself as a Stoic, Cicero's ethical thought was profoundly shaped by Stoic ethics. Although, as a skeptic, Cicero keeps himself from endorsing the arguments by which the Stoics explain and justify ethical obligations, he is aware of them and presents them in a sympathetic manner. Within de Natura Deorum 2 Cicero presents a sympathetic account of Chrysippus' understanding of the world as a unified living whole and a divinely run political community; this, as we have seen, is the philosophical basis of Chrysippus' cosmopolitanism. De Finibus 3 62-8 offers an apparently sympathetic overview of the cosmopolitan thought typical of the middle Stoa. The reservations that Cicero expresses in these two works are at bottom epistemological, resulting from Cicero's sympathy with the Academy's skeptical challenges to Stoic views, not ethical, not to the effect that the precepts of Stoic ethics deviate too widely from commonly accepted norms. Thus it is no surprise to see cosmopolitan ethical themes within de Officiis. What is surprising, from the standpoint of the Middle Stoa, is that these coexist with a celebration of war and empire. ${ }^{31}$

The theoretical foundations given within de Officiis for both universal and particularistic obligations are thoroughly Stoic.

Perhaps, though, we should examine more thoroughly what are the natural principles of human fellowship and community (quae naturae principia sint communitatis et societatis humanae). First is something that is seen in the fellowship of the entire human race. For its bonding consists in reason and speech, which reconcile men to one another (conciliat inter se homines) and ... unite them through a kind of natural fellowship ... The most widespread fellowship existing among men is that of all with all others. ... [H]e $\langle$ Ennius $\rangle$ advises us that if any assistance can be provided without detriment to oneself, it should be given even to a stranger. (DO 150 $51)^{32}$

The term conciliat (translated "reconcile") is cognate to conciliato, one of Cicero's translations of oikeiosis. It is through a kind of oikeiōsis that all

31 Perhaps, as Darrell Dobbs has suggested to me, our surprise should be moderated, given the prephilosophical sense of oikeiosis as "taking possession of" (Thuc. Hist., 4.128.4) (a sense for which "appropriation" might not be a bad translation).

32 Translations are from Griffin and Atkins 1991. 
human beings come to recognize a natural kinship and community; the existence of this naturally-based community entails certain obligations. ${ }^{33}$ Cicero goes on to discuss other, narrower, communities such as family, household, and country. Each of these forms of community, too, entail certain duties; by definition, such duties are particularistic, not as such to be extended to all human beings. Although Cicero would no doubt be in sympathy with Hierocles' exhortation that we treat those in more distant circles of relatedness as though they belonged to less distant circles, he would emphasize that the teleological structure of human society demands that there be limits to this process; it is neither possible nor desirable that there be equal oikeiosis with all rational beings. ${ }^{34}$ Although Cicero says that our obligations are greatest towards country and parents (1 58) neither closer nor more distant bonds necessarily trump the other. The degree to which our obligations to others are binding depends on context and circumstance (159).

As in the case of the passage from Plato with which we began, the issue of the difference between how we are to treat those who are in some sense our own and how we are to treat those who are not emerges most pointedly in a discussion concerning the ethics of warfare. Cicero presents a justification of war that on first sight is wholly in line with cosmopolitan principles: "Wars ... ought to be undertaken for this purpose, that we may live in peace, without injustice; and once victory has been secured, those who were not cruel or savage in warfare should be spared" (1 34). Peace and justice are principles of universal application, which Cicero takes the Roman fetial laws to exemplify. This might lead to the impression that Cicero advocates the use of military force only for the sake of peacekeeping and the enforcement of universal standards of right, not in the pursuit of national goals. Were this the case, Cicero's military ethics would be cosmopolitan through and through.

But the contemporary reader is surprised to read "When, then, we are fighting for empire and seeking glory through warfare, those grounds that

33 Thus at 1149 , Cicero writes "[W]e ought to revere, to guard, and to preserve the common affection (conciliationem) and fellowship of the whole of mankind".

34 On this see Nussbaum 1997, 9: "The Roman Stoics held, it seems, that we will not get good rearing of children by leaving all children equally to the care of all parents. ... [T] his should not be done from a sense that my children are really more worthwhile than other people's children, but from a sense that it makes most sense for me to do my duties where I am placed, that the human community is best arranged in that way. That, to a Stoic, is what local and national identities should be like, and that is how they can be fortified and encouraged without being subversive of the primary claim of humanity". This is true. But Nussbaum does not discuss and apparently minimizes the severe tension that can arise between such special obligations and cosmopolitan ideals. Cicero, I believe, is sensitive to them. 
I mentioned a little above as just grounds for war should be wholly present. But wars in which the goal is the glory of empire are waged less bitterly". We are to wage war differently when engaged in expanding the Roman empire "just as in civilian matters we may compete in one way with an enemy, in another way with a rival (for the latter contest is for honor and standing, the former for one's civic life or reputation)" (1 38). Is there a way to interpret Cicero as saying that a war of imperial conquest is to be justified as in the interests of justice or peace? Perhaps yes; perhaps Cicero is restricting his remarks on the ethics of war for empire to the Rome of his time, in the belief that Rome has a unique role in promoting the international good, for which reason a war of Roman imperial conquest would be fundamentally ethical. But this line of interpretation is unlikely. It is true that Cicero takes Rome to have had such a role historically, but he makes clear that with the ascension of Caesar that is no longer the case (2 27-30). Cicero is best understood as making a general claim about wars of empire. One is not obligated to wage them as a matter of justice. On the other hand, as Cicero sees it, such wars are no more intrinsically unjust than any competition with a rival. They are, after all, the means by which the superior and genuinely authoritative may legitimately prevail. ${ }^{35}$ (Cicero would not condemn such a war as unjust on the grounds that it involves theft, for 121 makes clear that Cicero thinks that one has a legitimate claim to property acquired through conquest.) Further, as long as the conquest is decisive, and the defeated are treated in a humane manner, the war of empire has peace as its result.

Cicero, clearly, is no pure cosmopolitan. War that is waged for the sake of the exclusive gain of one's own country is thought to be (in principle) legitimate and to be consistent with the cosmopolitan ideas that $\mathrm{Ci}$ cero has expressed. Nonetheless, whether because the dangers of defeat are less dire, or because there is a special kind of fellowship that binds agonic adversaries, Cicero emphasizes that the ethical standards for the conduct of such wars are even stricter than they would be otherwise. He admires those soldiers, whether serving Rome or its enemies, that hold to these high standards, and fulfill such obligations as keeping one's word and treating the vanquished with mercy $(138,3$ 107-15). From the point of view of a late Stoic like Cicero's likely philosophical source Paneatius, all such soldiers are doing the job that has been appointed to them in the

35 Nussbaum 1997, 11, in contrast, emphasizes 134 , in which Cicero asserts that the only legitimate reason for going to war is to live in peace, unharmed (an anticipation of Grotius; see Bederman 1996, 37-38), in which case, as Nussbaum recognizes (14), there is an insoluble conflict with Cicero's endorsement of "colonial conquest". Alas, I maintain that interpreter's charity demands that we interpret "living in peace" in 1 34 as "living in peace, while fulfilling one's legitimate role of prevailing over the uncivilized or weak". 
cosmic polis as it is, which is in part constituted by societies, as they are, not by a nonexistent polis, like that described in Zeno's Republic (which could only exist if all were sages). That this job involves the soldier's doing injury to the enemy is not thought to tell against the view that the soldier and the enemy are at bottom akin, and bound by cosmopolitan bonds of justice.

Perhaps, if we look away from Cicero's typically Roman focus on military virtues and duties, there is something to be said for Cicero's strategy of admitting both universal and particularistic obligations of justice. A number of philosophers today express dissatisfaction with the strict demands for impartiality required by classical Kantian and utilitarian ethics. ${ }^{36}$ The theoretical approaches taken by such thinkers are widely disparate; they run the gamut from socially conservative communitarianism of an Aristotelian or Confucian ilk to feminist ethical theories that place emphasis on special relations of caring, taken to be the result of spontaneous feeling or autonomous choice. They are united in taking as their starting point common moral judgments that endorse the ethical prioritizing of the welfare of the near and dear over strangers, in the spirit of "charity begins at home". (Thus, in spite of the condemnation of utilitarian ethical theory, ${ }^{37}$ one might well think that morality demands that a nation offer food and health care to its own citizens before transferring its wealth to societies suffering from more grinding poverty. Likewise, one might well think that morality requires spending money on special opportunities for one's own children, even if that entails spending less on meeting more basic needs of other children.) But there are severe ethical difficulties invited by such an approach. When do the obligations of community or care cross the line to morally objectionable varieties of nationalism, tribalism and prejudice? The approach of the Late Stoa, as found in the thought of Cicero, in principle offers a way to answer such questions. When cosmopolitan demands of impartial justice sit ill with the special obligations that we have to family and fellow citizens, those who are oikeioi in a narrow sense, one needs to refer to the obligations to the metaphysical bonds of kinship and fellowship that are the sources of the respective ethical obligations. The teleological importance of these bonds in part $^{38}$ determine the strength of the ethical claims that result from them. Both kinds of ethical obligations are real, and there is no easy formula by which they can be prioritized, in general or in particular cases. ${ }^{39}$

See Gilligan 1993, Miller 1988, Sommers 1986, Wong 1989.

See Singer 1972, 1993, 242-244.

No doubt a weighing of consequences will also play a role.

39 Sherman 2005, 172 suggests we are more apt to act appropriately, and to avoid the sort of abuses found at Abu Ghraib, by imagining others as within our inner circle, a 
An adequate grasp of these connections will allow one to see which is more binding in the particular circumstances in which conflicts arise. But such theoretical ethical resources have their cost: a thick cosmic metaphysics of the sort unfashionable today, and insuperable epistemological problems in determining exactly what the relevant bonds of oikeiosis are. The result is what we see in Cicero: the use of late Stoic cosmopolitan theory to often endorse but seldom challenge the kinds of ethical prioritization found in one's own society.

With Cicero, then, ancient philosophical treatments of the ethical obligations owed to those of a different kind or society have, in a sense, circled back to their prephilosophical origins. For as we have seen, within the Republic Socrates gives voice to common conventional morality, according to which there is a kind of natural war between different groups of people, and ethical bonds of fellowship exist only among those united by culture or blood. Plato himself offers the theoretical resources for showing the limitations and flaws of such parochial morality, and it may well be the case that Socrates' (morally objectionable) views in the Republic are not those of Plato. The middle Stoics exploit these Platonic resources to argue for a strict, impartial cosmopolitan ethics. At the same time, they recognized the ethical importance of special, exclusive varieties of human relatedness, as grounded in the cosmic teleological order. These are, unfortunately, exploited in Cicero's adaptation of late Stoic thought, in such a way that conflict among peoples is once again endorsed as a result of the natural order of things. Nonetheless, Cicero's advice is moderated by the cosmopolitanism of the Middle Stoa, when he urges that societies in competition must wage war in a spirit of justice and decency.

\section{Bibliography}

Annas, J. 1993. The Morality of Happiness. New York.

Bederman, D. J. 1996. "Reception of the Classical Tradition in International Law: Grotius' De Jure Belli ac Pacis". Emory International Law Review 10, 1-49.

Bees, R. 2004. Die Oikeiosislehre der Stoa: 1. Rekonstruktion ihres Inhalts. Würzburg. Brink, C. O. 1956. "Oikeiōsis and Oikeiotès: Theophrastus and Zeno on Nature in Moral Theory”. Phronesis 1, 123-45.

la Hierocles. For another approach, see G. Striker's "Following Nature” in Striker 1996, 256-261 who suggests that priority principles are needed to deal with this sort of conflict, and argues that an appeal to nature, the Stoics' only theoretical resource for deriving such principles, is not up to the task. But why cannot the middle Stoics have understood such a conflict as a prudential matter, in which all of the relevant contextual factors would be such as to be accurately gauged and evaluated by the sage? 
Cooper, J. 1995. "Eudaimonism and the Appeal to Nature in the Morality of Happiness: Comments on Julia Annas, The Morality of Happiness". Philosophy and Phenomenological Research 55, 594-598.

Dirlmeier, F. 1937. Die Oikeiosis-Lehre Theophrasts. Leipzig.

Engberg-Pederson, T. 1990. The Stoic Theory of Oikeiosis. Arhuss.

Gilligan, C. 1993. In a Different Voice. $6^{\text {th }}$. ed. Cambridge, MA.

Görgemanns, H. 1983. "Oikeiōsis in Arius Didymus". In W. Fortenbaugh, ed., On Stoic and Peripatetic Ethics: the Work of Arius Didymus. Ed. New Brunswick, 165-189.

Griffin, M. T./Atkins, E. M. (tr.). 1991. Cicero: On Duties. Cambridge.

Inwood, B. 1983. "Comments on Professor Görgemanns' Paper”. In W. Fortenbaugh, ed. On Stoic and Peripatetic Ethics: the Work of Arius Didymus. New Brunswick, 190-199.

Kerferd, G. B. 1972. "The Search for Personal Identity in Stoic Thought". Bulletin of the John Redlands University Library of Manchester 55, 177-96.

Long, A. A./Sedley, D. M. 1987. The Hellenistic Philosophers. 2 vols. Cambridge.

Miller, D. 1988. “The Ethical Significance of Nationality”. Ethics 98, 647-62.

Norlin, G. 1928. Isocrates with an English Translation in Three Volumes. Vol. 1. Cambridge, MA.

Nussbaum, M. C. 1997. "Kant and Stoic Cosmopolitanism". Journal of Political Philosophy 5, 1-25.

Nussbaum, M. C. et al. 1996. For Love of Country: Debating the Limits of Patriotism. Boston.

Pembroke, S. G. 1971. “Oikeiōsis”. In A. A. Long, ed., Problems in Stoicism. London, $114-149$.

Pohlenz, M. 1940. Grundfragen der Stoischen Philosophie. Gottingen.

Sellars, J. 2007. "Stoic Cosmopolitanism and Zeno's Republic". History of Political Thought 28, 1-29.

Schofield, M. 1999. The Stoic Idea of the City. Chicago.

Sherman, N. 2005. Stoic Warriors: The Ancient Philosophy Behind the Military Mind. Oxford.

Shorey, P. 1929. "Plato and the Stoic Oikeiosis in the Berlin Theaetetus Commentary" Classical Philology 24, 409-10.

Singer, P. 1972. "Famine, Affluence, and Morality". Philosophy and Public Affairs 1, 229-43.

Singer P. 1993. Practical Ethics. $2^{\text {nd }}$ ed. Cambridge.

Sommers, C. H. 1986. "Filial Morality". The Journal of Philosophy 83, 439-456.

Striker, G. 1996. Essays on Hellenistic Epistemology and Ethics. Cambridge.

Vogt, K. M. 2008. Law, Reason, and the Cosmic City: Political Philosophy in the Early Stoa. Oxford.

Wachsmuth, C./Hense, O. eds. 1884. Ioannis Stobaei Anthologium, vol. 2.

Wong, D. B. 1989. "Universalism Versus Love with Distinctions: An Ancient Debate Revived”. Journal of Chinese Philosophy 16, 251-72. 